medRxiv preprint doi: https://doi.org/10.1101/2022.02.08.22270624; this version posted February 9, 2022. The copyright holder for this preprint (which was not certified by peer review) is the author/funder, who has granted medRxiv a license to display the preprint in perpetuity. It is made available under a CC-BY-NC-ND 4.0 International license .

Running Head: Heterogeneity of Irritability

\title{
Heterogeneity of Irritability: Psychometrics of The Irritability and Dysregulation of Emotion Scale (TIDES-13).
}

Andrew S. Dissanayake ${ }^{1}$; Annie Dupuis, $\mathrm{PhD}^{2}$; Paul D. Arnold, MD, $\mathrm{PhD}^{1,3,4}$; Christie Burton, $\mathrm{PhD}^{3}$; Jennifer Crosbie, $\mathrm{PhD}^{1,3}$; Russell J. Schachar, $\mathrm{MD}^{1,3}$; Tomer Levy, $\mathrm{MD}^{5,6}$

${ }^{1}$ Department of Psychiatry, Hospital for Sick Children, Toronto, ON, Canada, ${ }^{2}$ Department of Biostatistics, Dalla Lana School of Public Health, University of Toronto, Canada ${ }^{3}$ Department of Psychiatry, Faculty of Medicine, University of Toronto, Canada, ${ }^{4}$ The Mathison Centre for Mental Health Research \& Education, Department of Child and Adolescent Psychiatry, Shalvata Mental Health Center, Hod Hasharon, Israel ${ }^{5}$, Sackler Faculty of Medicine, Tel Aviv University, Tel Aviv, Israel ${ }^{6}$.

\section{Corresponding Author:}

Russell J. Schachar, MD

Senior Scientist and Staff Psychiatrist

The Hospital for Sick Children (Neurosciences and Mental Health/Psychiatry)

Phone: 416.813 .7654 ex 206564

Fax: 416.813.6565

Email: russell.schachar@sickkids.ca

Acknowledgements: This work was supported by the Canadian Institutes of Health Research (R.J.S., MOP-93696 and P.D.A., MOP-106573) and the Alberta Innovates Translational Health Chair in Child and Youth Mental Health (P.D.A.). The statistical expert on the manuscript is Dr. Annie Dupuis.

Keywords: Irritability, Heterogeneity, TIDES-13, psychometric properties, scale validation Conflict of interest: None. 
Running Head: Heterogeneity of Irritability

\title{
Heterogeneity of Irritability: Psychometrics of The Irritability and Dysregulation of
}

\section{Emotion Scale (TIDES-13).}

\author{
ABSTRACT \\ Objective. We designed The Irritability and Dysregulation of Emotion Scale (TIDES-13) to test \\ whether irritability consisted of several sub-dimensions that would correlate differentially with \\ internalizing/externalizing psychopathology, age, and gender. Method. Parent-report ( $\mathrm{n}=3935$, \\ mean age $=8.9)$ and youth self-report $(\mathrm{n}=579$, mean age $=15.1)$ versions of TIDES-13 were \\ administered to a population-based sample. Exploratory and confirmatory factor analyses were \\ conducted on separate sub-samples. We fit multivariable regression models between TIDES-13 \\ sub-dimensions and age, gender, anxiety, depression, ODD and ADHD trait levels. Results. A \\ higher order model with a global irritability dimension and Proneness to Anger, Internalized \\ Negative Emotional Reactivity, Externalized Negative Emotional Reactivity and Reactive \\ Aggression sub-dimensions showed good to excellent fit in both parent-report and self-report. \\ The global irritability dimension had a strong influence on all item variance (WHierarchical; parent report \\ $=.0 .94$, WHierarchical; self report $=.90)$. Proneness to Anger, Externalized Negative Emotional \\ Reactivity and Reactive Aggression decreased with age in males, whereas Internal Negative \\ Emotional Reactivity increased with age in females. Internalized Negative Emotional Reactivity \\ was associated with internalizing traits, over and above global irritability. ODD and ADHD were \\ predicted primarily by the global irritability. Conclusion. Although irritability can be estimated \\ as an essentially unidimensional construct, differential associations of Internalized Negative \\ Emotional Reactivity with gender and age, and internalizing psychopathology warrant \\ examination in clinical populations. These results support TIDES-13 as a reliable and valid
}


medRxiv preprint doi: https://doi.org/10.1101/2022.02.08.22270624; this version posted February 9, 2022. The copyright holder for this preprint (which was not certified by peer review) is the author/funder, who has granted medRxiv a license to display the preprint in perpetuity.

It is made available under a CC-BY-NC-ND 4.0 International license .

multidimensional measure of irritability and thus may be useful for research and clinical purposes.

\section{INTRODUCTION}

Irritability is the one of the most common reasons for psychiatric evaluation and treatment in children and youth. ${ }^{1,2}$ Irritability is associated with a wide range of internalizing (eg. anxiety and depression $)^{3}$ and externalizing psychopathology (eg. attention-deficit/hyperactivity disorder $(\mathrm{ADHD})^{4}$ and oppositional defiant disorder $\left(\mathrm{ODD}^{5}\right)$ and predicts significant concurrent and future impairment (eg. academic problems, poverty, and suicidality). ${ }^{6,7}$ Despite its importance, there is a lack of consensus on how to best conceptualize and measure irritability. ${ }^{8}$ This difficulty arises because irritability may manifest through a wide range of emotions, behaviors and internal states. ${ }^{9}$ For example, irritability may encompass excessive reaction to external (e.g., auditory stimulus, external cognitive distraction) or internal stimuli (e.g., fatigue or hunger) with negative emotions (ie. negative emotional reactivity), ${ }^{10-12}$ proneness to anger outbursts (i.e., "phasic irritability"), persistent irritable moods (i.e, tonic irritability), ${ }^{13}$ low tolerance for frustration in the face of blocked goal attainment (i.e., frustration intolerance), ${ }^{14,15}$ and a low threshold for maladaptive responses to threat with reactive aggression. ${ }^{11,16}$

Existing measures focus on a subset of possible manifestations of irritability, treating the construct as a homogeneous or unidimensional construct rather than a heterogeneous or multidimensional concept obscuring the possibility that sub-dimensions of irritability may exist and have distinct correlates. For example, the Affective Reactivity Index (ARI), a widely-used six item irritability scale in children and youth, primarily includes items that center on expressions of anger"17 (ie.."stays angry for a long time", "is angry most of the time", "gets angry frequently"). On the other hand, the Bite Scale includes only items pertaining to an internal 
medRxiv preprint doi: https://doi.org/10.1101/2022.02.08.22270624; this version posted February 9, 2022. The copyright holder for this preprint (which was not certified by peer review) is the author/funder, who has granted medRxiv a license to display the preprint in perpetuity.

It is made available under a CC-BY-NC-ND 4.0 International license .

enduring state, alternatively characterized as tonic irritability ${ }^{18,19}$ (ie. "I have been grumpy, other people have been getting on my nerves", "Things have been bothering me more than they normally do", "I have been feeling irritable"). Despite these unidimensional conceptualizations, there is growing evidence for the hypothesis that irritability is a multidimensional trait with subdimensions that represent different states, emotions and behaviors. ${ }^{19-22}$ Thus, a measure that encompasses the variable sub-dimensions of irritability with strong internal reliability and discriminant validity would be an asset to clinical practice and scientific research progress..$^{8,9,17}$

Prior to this study, we developed The Irritability and Dysregulation of Emotion Scale (TIDES-13) to measure a wide range of theoretical manifestations of the construct including proneness to anger (i.e., tonic irritability), ${ }^{16}$ anger outbursts (i.e., phasic irritability), ${ }^{10} 12,18$ negative emotional reactivity, ${ }^{12}$ and frustration intolerance ${ }^{13}$ (see supplementary materials). This present study assessed whether TIDES-13 captured a unified construct corresponding to irritability, as described previously in the literature, or whether irritability consists of subdimensions with distinct correlates. Using data from a large community sample, we used exploratory and confirmatory factor analyses to determine whether multiple irritability subdimensions could be discerned. Finally, we assessed the predictive validity of irritability subdimensions by examining their differential associations with age, gender, internalizing psychopathology and externalizing psychopathology. ${ }^{19-22}$ We also tested the hypothesis that a sub-dimension pertaining to anger would show the strongest levels of convergence with the ARI, given that the ARI mainly measures proneness to anger. ${ }^{8}$

\section{METHOD}

Methods for Scale Development are described in the supplement. 
medRxiv preprint doi: https://doi.org/10.1101/2022.02.08.22270624; this version posted February 9, 2022. The copyright holder for this preprint (which was not certified by peer review) is the author/funder, who has granted medRxiv a license to display the preprint in perpetuity.

It is made available under a CC-BY-NC-ND 4.0 International license .

\section{Participants}

Visitors aged 4-19 years to a local science center $(\mathrm{N}=4413)$ participated in this study in 2019. Sample characteristics are presented in Table 1. Parents were the informants for participants ages 4 to $19(\mathrm{~N}=3880)$; participants aged 10-19 $(\mathrm{N}=533)$ provided self-report.

\section{Ethical considerations}

Informed consent, and verbal assent when applicable, were obtained from all participants, as approved by the local institution's ethics review board.

\section{Predictive Validity}

To assess the predictive validity of irritability sub-dimensions, a subsets of parents and youth completed the ARI (parent: $\mathrm{N}=802$; self: $\mathrm{N}=77$ ), as well as measures of ADHD (parent: $\mathrm{N}=3867$; self: $\mathrm{N}=516$ ) ODD (parent: $\mathrm{N}=1256$; self: $\mathrm{N}=54$ ), anxiety (parent: $\mathrm{N}=1554$, self: $\mathrm{N}=109$ ) and depression (parent: $\mathrm{N}=1555$; self: $\mathrm{N}=109$ ) traits. Anxiety and Depression traits were measured by summing the 6 item depression subscale and the 10 item subscale of the Revised Children's Anxiety and Depression Scale-25 (RCADS). ${ }^{23}$ ADHD and ODD traits were measured by summing the 18 ADHD items and the 8 ODD items, respectively, in the Strength and Weakness of ADHD and Normal behavior scale (SWAN) ${ }^{24}$ SWAN scores were reversed so that higher scores reflected higher levels of the trait for consistency with the other measures.

\section{Statistical Analyses}

To evaluate TIDES-13's dimensionality, we randomly split the parent-report data into an exploratory factor analysis (EFA) sample $(\mathrm{N}=1937)$ and a confirmatory factor analysis sample (CFA; $\mathrm{N}=1938)$. The self-report sample $(\mathrm{N}=516)$ was used entirely for CFA. Detailed 
medRxiv preprint doi: https://doi.org/10.1101/2022.02.08.22270624; this version posted February 9, 2022. The copyright holder for this preprint (which was not certified by peer review) is the author/funder, who has granted medRxiv a license to display the preprint in perpetuity.

It is made available under a CC-BY-NC-ND 4.0 International license .

procedure for the EFA can be found in the supplemental materials. In CFA, we used a robust maximum likelihood estimator (MLR) due to moderate violations to multivariate normality, as indicated by visual examinations of the Chi-Squared Q-Q plot. Model fit was assessed based on the following fit indices: Comparative Fit index (CFI;.95 and above indicate excellent fit whereas .90-0.95 indicate acceptable fit), the Tucker Lewis Index (TLI; values above .95 indicate excellent fit whereas $.90-.95$ indicate acceptable fit), the root means square error of approximation (RMSEA; values smaller than .08 indicate acceptable fit), and the standardized root mean square residual (SRMR; recommended cut-off at .08$).{ }^{25} \mathrm{We}$ additionally tested the fit of multiple higher order models with a single higher order global dimension and the subdimensions extracted from EFA to assess the degree to which the sub-dimensions of irritability, in fact, contributed to a single underlying construct. To compare the relative contributions of a higher order global dimension versus each sub-dimension to the item's variance, we performed Schmid-Leiman transformations ${ }^{26}$ to the best fitting higher order model, which enabled variance partitioning between global dimensions and the sub-dimensions. We also used the standardized loadings from the Schmid-Leiman transformations to calculate indices of internal consistency reliability (ie. the proportion of variance in the calculated score attributed to the construct of interest $).{ }^{27}$ We calculated omega total, omega hierarchical $\left(\omega_{\mathrm{h}}\right)$, and omega sub-dimension. Omega total estimates the proportion of variance of a total score attributable to all sources of common variance, where a high omega value reflects a highly reliable multidimensional composite ${ }^{28} \omega_{\mathrm{h}}$ represents the proportion of variance attributable to a common factor and is a measure of general factor saturation, ${ }^{28}$ where a high $\omega_{\mathrm{h}}$ indicates that the general factor is a dominant source of test score variance. ${ }^{29}$ Omega sub-dimension represents the internal consistency reliability of each sub-dimension score to measure the corresponding sub-dimension, 
medRxiv preprint doi: https://doi.org/10.1101/2022.02.08.22270624; this version posted February 9, 2022. The copyright holder for this preprint (which was not certified by peer review) is the author/funder, who has granted medRxiv a license to display the preprint in perpetuity.

It is made available under a CC-BY-NC-ND 4.0 International license .

over and above the global construct. ${ }^{30}$ Each omega value can range from 0 (no reliability) to 1 (perfect reliability). CFA models were fitted using lavaan ${ }^{31}$ and the Schmid-leimen transformation and omega values were calculated using EFAtools. ${ }^{32}$ Both packages are freely available in R Studio.

Multivariable regression models were fit to examine associations of TIDES-13 subdimensions with age and gender. Age by gender interactions were also examined, and a subsequent gender-stratified analysis was performed when the interaction term was significant. Parent and self-report data were combined to examine the associations between irritability and age along the full age continuum (ie. 4-19 yrs), with adjustment for respondent.

We evaluated the associations of each TIDES sub-dimension with anxiety, depression, ADHD and ODD traits by first calculating the Pearson correlations between each trait measure and each TIDES-13 sub-dimension in the subsample of participants with both measures available. We compared the TIDES-13 sub-dimensions correlation between other outcome variables and other sub-dimensions using Hitner's, May and Silver's method for comparing dependent correlations. ${ }^{33}$ We then fit multivariable regression models for each outcome with each TIDES sub-dimension as a predictor, adjusting for covariates such as age and gender. Parent-reported outcomes were predicted by parent-reported variables; self-reported outcomes were predicted by self-reported variables. To test the degree to which associations were driven by variance unique to specific sub-dimensions or rather by shared variance between each subdimension (i.e., the global factor), we performed a regression commonality analysis. ${ }^{34}$ Variance inflation factors (VIF) were also calculated to ensure the results were not severely degraded by multicollinearity. VIF's under 10 were considered acceptable with no severe violations. ${ }^{35}$ Statistical significance was considered at $p<.05$ for all analyses. 


\section{Dimensionality}

\section{RESULTS}

EFA and CFA revealed a four-dimension model with dimensions corresponding to Proneness to Anger (P. Anger), Reactive Aggression (R. Aggression), externalized negative emotional reactivity (Ext. Reactivity), and internalized negative emotional reactivity (Int. Reactivity) fit the data best in both parent-report and self-report. However, as model selection based fit statistics is generally unadvisable,$^{30}$ we further examined the corresponding higher order model with the same four dimensions as sub-dimensions and an additional higher order global irritability (IRRIT) dimension (Figure 1) due to the moderate to high inter-dimension correlations (Table 2). This higher order model showed excellent fit in parent-report data $\left(\mathrm{CFI}_{\text {parent }}=.973, \mathrm{TLI}_{\text {parent }}=.965, \mathrm{RMSEA}_{\text {parent }}=.76, \mathrm{SRMR}=.027\right)$ and self-report data $\left(\mathrm{CFI}_{\text {self }}\right.$ $\left.=.971, \mathrm{TLI}_{\text {self }}=.944, \mathrm{RMSEA}_{\text {self }}=.78, \mathrm{SRMR}=.044\right)$. The loadings of the higher order model with four sub-dimensions (Figure 1) revealed that each item influenced its corresponding subdimension $\left(\lambda_{\text {parent }}>.74 ;\right.$ Median $\lambda_{\text {parent }}=.88 ; \lambda_{\text {self }}>.61 ;$ Median $\left.\lambda_{\text {self }}=.82\right)$, indicating that the sub-dimensions were well defined.

The loadings of the sub-dimensions onto the global irritability dimension (from $\lambda_{\text {parent }}=$ .86 (R. Aggression) to $\lambda_{\text {parent }}=.98$ (P. Anger); from $\lambda_{\text {self }}=.85$ (R. Aggression) to $\lambda_{\text {self }}=.96(\mathrm{P}$. Anger) demonstrated that each the sub-dimension was strongly influenced by IRRIT (Figure 1). The high standardized loadings from the Schmid-Leiman transformation of the higher order four sub-dimension model (Table 3) also suggested a strong underlying global irritability dimension. The median of the standardized item loadings on IRRIT was $\lambda=.81$ (range: $\lambda=.72$ to $\lambda=.92$ ) in 
medRxiv preprint doi: https://doi.org/10.1101/2022.02.08.22270624; this version posted February 9, 2022. The copyright holder for this preprint (which was not certified by peer review) is the author/funder, who has granted medRxiv a license to display the preprint in perpetuity.

It is made available under a CC-BY-NC-ND 4.0 International license .

parent report and $\lambda=.72$ (range: $\lambda=.58$ to $\lambda=.87$ ) in self-report. However, each item also had consistent non-negligible loadings onto its corresponding sub-dimensions (Median $\lambda_{\text {parent }}=.24$; range: from $\lambda_{\text {parent }}=.18$ to $\lambda_{\text {parent }} .46 ;$ Median $\lambda_{\text {self }}=.24 ;$ range: from $\lambda_{\text {self }}=.24$ to $\left.\lambda_{\text {self }}=.46\right)$ which suggested that the sub-dimensions had incremental impact on the corresponding item scores over and above IRRIT. Descriptions of all models that were extracted in EFA and compared in CFA, along with their respective fit indices, can be found in the supplemental materials along with their respective fit indices in Table $\mathrm{S} 1$.

Model-based omega estimates suggested that IRRIT had excellent internal consistency reliability and contributed to a large proportion of the total variance of all the items (Table 3). All estimated omega values can be found in Table 3. The $\omega_{\mathrm{h}}$ values for each sub-dimension were satisfactory to excellent $\left(\right.$ Median $\omega_{\mathrm{H} \text { parent }}=.81$; range: from $\omega_{\mathrm{H} \text { parent }}=.67(\mathrm{R}$. Aggression $)$ to $\omega_{\mathrm{H}}$ parent $.89\left(\mathrm{P}\right.$. Anger); Median $\omega_{\mathrm{H} \text { self }}=.68$; range: $\omega_{\mathrm{H} \text { self }}=.63$ to $\left.\omega_{\mathrm{H} \text { self }}=.81\right)$. The $\omega_{\mathrm{h}}$ value corresponding to IRRIT was very high in parent report $\left(\omega_{\mathrm{H}}=.94\right)$ and self report $\left(\omega_{\mathrm{H}}=.90\right)$ suggesting a strong underlying global factor. Correspondingly, the omega sub-dimension values for the sub-dimensions were low (Median $\omega_{\text {parent }}=.11$; range: $\omega_{\text {parent }}=.04$ to $\omega_{\text {parent }} .25$; Median $\omega_{\text {self }}=.14$; range: $\omega_{\text {self }}=0.08$ to $\left.\omega_{\text {self }}=.24\right)$, further confirming that a large proportion of the reliable variance was captured by IRRIT

\section{Predictive Validity of TIDES-13 sub-dimensions}

In multivariable regression models examining age and gender effects, the age by gender interaction terms were significant for each sub-dimension. In subsequent gender stratified analyses, IRRIT, P. Anger, Ext. Reactivity and R. Aggression decreased with age in males but 
medRxiv preprint doi: https://doi.org/10.1101/2022.02.08.22270624; this version posted February 9, 2022. The copyright holder for this preprint (which was not certified by peer review) is the author/funder, who has granted medRxiv a license to display the preprint in perpetuity.

It is made available under a CC-BY-NC-ND 4.0 International license .

showed no significant associations with age in females whereas Int. Reactivity increased with age in females but showed no significant associations with age in males (Table S2).

In parent- and self-report, Int. Reactivity was significantly more correlated with anxiety traits than all the other TIDES-13 sub-dimensions (Table 2): P. Anger (parent: $\mathrm{z}=6.47, \mathrm{p}<.001$; self: $\mathrm{z}=3.53, \mathrm{p}<.001$ ), Ext. Reactivity (parent: $\mathrm{z}=3.38, \mathrm{p}<.001$; self: $\mathrm{z}=2.3, \mathrm{p}=.021$ ), and R. Aggression (parent: $\mathrm{z}=5.58, \mathrm{p}<0.001$; self: $\mathrm{z}=2.55, \mathrm{p}=.011$ ). Similarly, parent reported Int. Reactivity was also significantly more correlated with depression traits than all the other subdimensions (Table 2): P. Anger $(z=5.74, p<.001)$, Ext. Reactivity $(z=3.86, p<0.001)$ and $R$. Aggression $(\mathrm{z}=5.23, \mathrm{p}<.001)$. Self-reported Int. Reactivity was significantly more correlated with depression traits than P. Anger $(z=2.64, p=.008)$ and R. Aggression $(z=2.37, p=.018)$ but no significant differences were found when compared to the correlation between depression traits and Ext. Reactivity $(\mathrm{z}=1.69, \mathrm{p}=.092)$.

As expected, P. Anger had the highest correlation with the ARI (Table 2). Parentreported P. Anger was significantly more correlated with the ARI than Ext. Reactivity $(z=3.7, p$ $<.001)$ and R. Aggression $(\mathrm{z}=4.56, \mathrm{p}<.001)$ however, no significant difference was found between the correlation of the ARI and P. Anger, and the correlation of the ARI and Int. Reactivity $(\mathrm{z}=1.36, \mathrm{p}=.174)$. Self-reported P. Anger was significantly more correlated with the ARI than Ext. Reactivity was $(\mathrm{z}=1.20, \mathrm{p}=.048)$, but no significant differences were found when comparing the correlation of the ARI and P. Anger to the correlation of the ARI and Int. Reactivity $(\mathrm{z}=0.31, \mathrm{p}=.757)$ and the correlation of the ARI and R. Aggression $(\mathrm{z}=0.06, \mathrm{p}=$ $.952)$.

Parent-reported P. Anger was significantly more correlated with ODD traits than Int. Reactivity $(z=5.79)$, Ext. Reactivity $(z=3.2, p=.0013)$ and R. Aggression $(z=3.40, p=$ 
medRxiv preprint doi: https://doi.org/10.1101/2022.02.08.22270624; this version posted February 9, 2022. The copyright holder for this preprint (which was not certified by peer review) is the author/funder, who has granted medRxiv a license to display the preprint in perpetuity.

It is made available under a CC-BY-NC-ND 4.0 International license .

.0007). In self-report, although, R. Aggression had the greatest correlation with ODD traits, it was not significantly greater than the correlations between ODD traits and the other subdimensions

In multivariable regression models, Int. Reactivity was the strongest significant predictor (i.e., largest beta coefficient) of anxiety and depression (Table 4). A similar trend was seen in self-report, where Int. Reactivity was the sole significant predictor of anxiety and depression traits (Table 4). Further commonality analysis revealed that in parent report data, Int. Reactivity uniquely explained $31.1 \%$ and $23.9 \%$ of the total variance explained by the regression models predicting anxiety and depression traits respectively, whereas $41.5 \%$ and $54.4 \%$ of the variance explained was shared by all sub-dimensions. These results suggest IRRIT explains a substantial portion of the anxiety and depression trait variance, however, Int. Reactivity is uniquely associated with internalizing traits, over and above the associations of IRRIT. In self-report data, surprisingly, a greater proportion of the variance of anxiety and depression traits was uniquely explained by Int. Reactivity (77.8\% and $78.3 \%$ respectively) than the variance explained by IRRIT (14.4\% and $11.4 \%$ respectively), suggesting that Int. Reactivity primarily predicted internalizing traits, even more so than IRRIT.

In multivariable regression models, parent reported P. Anger was the strongest predictor of ODD traits; however, substantially more of the variance explained by the model was shared by all sub-dimensions (60.4\%) than what was uniquely explained by P. Anger (6.9\%). In selfreported data, no sub-dimensions were significant predictors, however, there a limited number of self-report participants who had completed both the TIDES-13 and the ODD subscale $(\mathrm{n}=54)$. 
medRxiv preprint doi: https://doi.org/10.1101/2022.02.08.22270624; this version posted February 9, 2022. The copyright holder for this preprint (which was not certified by peer review) is the author/funder, who has granted medRxiv a license to display the preprint in perpetuity.

It is made available under a CC-BY-NC-ND 4.0 International license .

All sub-dimensions were similarly correlated with ADHD traits and had overlapping confidence intervals (Table 2). In regression models (Table 4), a majority of the variance explained was explained by IRRIT (parent report: $\%$ shared $=61.7$, self report: $\%$ shared $=48.8$ ).

\section{DISCUSSION}

This article examined the heterogeneity of irritability symptoms in a large community sample using TIDES-13, a novel scale designed to capture various expressions of irritability. Our first aim was to use exploratory and confirmatory factor analyses to see if irritability subdimensions could be discerned. Our results lend further support to the notion that irritability is a heterogeneous construct with highly interrelated, yet distinct, ways of manifesting. We identified highly correlated, but distinguishable sub-dimensions that showed excellent fit across respondents (parent vs self): P. Anger, R. Aggression, Int. Reactivity, and Ext. Reactivity. Three of these sub-dimensions aligned with our hypothesis that dimensions relating to proneness to anger, reactive aggression, and internal affective state (Int. Reactivity) would emerge. However, within the remaining items, an external (Ext. Reactivity) response to stimuli also emerged.

The empirical distinction between P. Anger, characterized by anger outbursts, and Int. Reactivity, an internal persistent state, within our results aligns with the a priori differentiation between phasic (i.e., severe and developmentally inappropriate anger outbursts) and tonic (ie. persistent irritable mood between outbursts) irritability. The separation of these two subdimensions is also consistent with recent empirical findings that suggest phasic and tonic irritability are distinct, yet highly related irritability dimensions..$^{19,21}$ 
medRxiv preprint doi: https://doi.org/10.1101/2022.02.08.22270624; this version posted February 9, 2022. The copyright holder for this preprint (which was not certified by peer review) is the author/funder, who has granted medRxiv a license to display the preprint in perpetuity.

It is made available under a CC-BY-NC-ND 4.0 International license .

The emergence of reactive aggression sub-dimension within our results is also important given the debate on whether notions of irritability should include behavioral aspects such as aggression. The result from our higher order modeling reveals that R. Aggression loaded onto the global factor (IRRIT) to a similar extent as other irritability sub-dimensions. This supports the conceptualization of R. Aggression as a distinguishable behavioral manifestation of irritability.

Given the calls for more nuanced irritability measures that are better able to differentiate irritability-related constructs such as tonic and phasic irritability from each other, ${ }^{19}$ having P. Anger, R. Aggression, Int. Reactivity, and Ext. Reactivity sub-dimensions within a measure of irritability may enable more nuanced explorations of the construct's phenomenology. However, we also found a high degree of unity within the isolated sub-dimensions, which may explain why irritable sub-dimensions have been so difficult to distinguish previously. We observed that P. Anger, R. Aggression, Int. Reactivity, and Ext. Reactivity showed high degrees of interrelatedness and loaded strongly onto a global dimension (IRRIT) with high internal reliability. Furthermore, when evaluating the association of sub-dimensions with other forms of psychopathology, we saw that ADHD and ODD traits were driven primarily by IRRIT rather than individual sub-dimensions. We also observed high $\omega_{\mathrm{h}}$ values of IRRIT (.94 and .90) suggesting that much of the item variance was driven by one underlying factor. These findings are consistent with studies conducted in a general population that suggest irritability subdimensions show high levels of inter-relatedness in normative samples. ${ }^{13}$ Paired with our findings, these studies suggest that within a normative sample, irritability can be considered essentially unidimensional implying the existence of a unique unidimensional latent trait in the presence of minor sub-dimensions. ${ }^{36}$ In light of these findings, we suggest that investigators 
medRxiv preprint doi: https://doi.org/10.1101/2022.02.08.22270624; this version posted February 9, 2022. The copyright holder for this preprint (which was not certified by peer review) is the author/funder, who has granted medRxiv a license to display the preprint in perpetuity.

It is made available under a CC-BY-NC-ND 4.0 International license .

using TIDES-13 to measure irritability in normative samples may utilize a total score as a valid and reliable measure of global irritability.

However, these results do not invalidate the potential of measuring irritability through sub-dimensions. Our results indicated that measuring irritability sub-dimensions provides additional information beyond irritability in general. We observed that Int. Reactivity increased with age in females and showed no association with age in males, contrary to the other subdimensions which decreased with age in males and showed no association in females. We also observed that Int. Reactivity was also uniquely associated with internalizing traits alluding to its discriminant validity. This differential association is consistent with work that suggests that mood-related irritability items predict depression in early adulthood over and above oppositional defiant dimension related items, ${ }^{20}$ lending support to the Int. Reactivity's predictive validity. Given the emerging consensus that irritability in children is a longitudinal predictor of anxiety and depression, ${ }^{3}$ further examination of the longitudinal associations with TIDES-13 subdimensions may also yield a better understanding of whether these associations are primarily driven by specific sub-dimensions of irritability. Furthermore, recent evidence suggests that different subtypes of irritability with different developmental trajectories may exist. ${ }^{22,37}$ One of these isolated subtypes showed an increasing association with age and female preponderance similar to Int. Reactivity's associations with age/gender, whereas other irritability subtypes show male preponderance and an inverse association with age, similar to the cross sectional trend observed in the remaining TIDES sub-dimensions. ${ }^{22}$ However, developmental studies often utilize overall irritability scores, combining items from the different potential sub-dimensions of 
medRxiv preprint doi: https://doi.org/10.1101/2022.02.08.22270624; this version posted February 9, 2022. The copyright holder for this preprint (which was not certified by peer review) is the author/funder, who has granted medRxiv a license to display the preprint in perpetuity.

It is made available under a CC-BY-NC-ND 4.0 International license .

irritability obscuring the possibility that these subtypes are driven by particular irritability subdimensions.

We also found that parent-reported P. Anger was more strongly correlated with the ARI than most other sub-dimensions confirming that ARI items tend to reflect proneness to anger. However, it should be noted that although the magnitude of correlation coefficients in self-report suggested a similar trend, many of the comparisons of correlation coefficients in self report were non-significant. This could be partially due to the limited power available due to the small subset of self respondents who completed both the ARI and TIDES-13 $(\mathrm{N}=73)$. Also, in the parent report, the differences in correlation coefficients between P. Anger and the ARI and Int. Reactivity and the ARI were non-significant. This may be due to the ARI's item content as five of the items relate to P. Anger, and one item taps into Int. Reactivity (i.e., "easily annoyed"). Further examination of the differences between P. Anger and Int. Reactivity may bring clarity as to whether any differences between the two constructs are being masked by combining into a single dimension within existing measures.

There are some limitations of this study that should be noted. The study sample was population-based, and thus the number of participants with mental-health diagnoses was proportional to that in a general population. However, an irritability scale with variable subdimensions such as TIDES-13 would enable evaluations of the factor structure in different clinical populations. Future validation studies for TIDES-13 should aim to replicate the factor structure and cross-sectional associations in clinical samples so that differences between irritability sub-dimensions can be further explored. The cross-sectional nature of our results also limited inferences about the stability and long-term predictive validity of irritability factor 
medRxiv preprint doi: https://doi.org/10.1101/2022.02.08.22270624; this version posted February 9, 2022. The copyright holder for this preprint (which was not certified by peer review) is the author/funder, who has granted medRxiv a license to display the preprint in perpetuity. It is made available under a CC-BY-NC-ND 4.0 International license .

structure found in the current study. Given the available data, we were only able to assess

TIDES-13's internal reliability. Future studies should administer TIDES to multiple raters across different respondents and different time points to examine the scale's test-retest and inter-rater reliability.

\section{CONCLUSIONS}

In a large general population sample with both self and parent report measures, we found unity and diversity between irritability sub-dimensions. Irritability can manifest variably as highly interrelated sub-dimensions P. Anger, Int. Reactivity, Ext. Reactivity and R. Aggression with distinct correlates of psychopathology. These results support TIDES-13 as a reliable and valid measure which captures a broader spectrum of the construct's phenotype and thus may be useful for research or clinical purposes. We specifically underscore a need to further examine the hypothesis that the association between irritability and internalizing psychopathology may be primarily driven by Int. Reactivity. 
medRxiv preprint doi: https://doi.org/10.1101/2022.02.08.22270624; this version posted February 9, 2022. The copyright holder for this preprint (which was not certified by peer review) is the author/funder, who has granted medRxiv a license to display the preprint in perpetuity. It is made available under a CC-BY-NC-ND 4.0 International license .

4. Eyre O, Langley K, Stringaris A, Leibenluft E, Collishaw S, Thapar A. Irritability in ADHD: Associations with depression liability. J Affect Disord. 2017;215:281-287. doi:10.1016/j.jad.2017.03.050

5. Burke JD, Boylan K, Rowe R, et al. Identifying the Irritability Dimension of ODD: Application of a Modified Bifactor Model Across Five Large Community Samples of Children. J Abnorm Psychol. 2014;123(4):841-851. doi:10.1037/a0037898

6. Copeland WE, Shanahan L, Egger H, Angold A, Costello EJ. Adult diagnostic and functional outcomes of DSM-5 disruptive mood dysregulation disorder. Am J Psychiatry. 2014;171(6):668-674. doi:10.1176/appi.ajp.2014.13091213

7. Conner KR, Meldrum S, Wieczorek WF, Duberstein PR, Welte JW. The association of irritability and impulsivity with suicidal ideation among 15- to 20-year-old males. Suicide Life Threat Behav. 2004;34(4):363-373. doi:10.1521/suli.34.4.363.53745

8. Toohey MJ, DiGiuseppe R. Defining and measuring irritability: Construct clarification and differentiation. Clin Psychol Rev. 2017;53:93-108. doi:10.1016/j.cpr.2017.01.009

9. Malhi G, Bell E, Outhred T. Getting irritable about irritability? Evid Based Ment Health. 2019;22(3):93-94. doi:10.1136/ebmental-2019-300101

10. Caprara GV, Cinanni V, D’Imperio G, Passerini S, Renzi P, Travaglia G. Indicators of impulsive aggression: Present status of research on irritability and emotional susceptibility scales. Personal Individ Differ. 1985;6(6):665-674. doi:10.1016/0191-8869(85)90077-7

11. Leibenluft E, Stoddard J. The developmental psychopathology of irritability. Dev Psychopathol. 2013;25(4 0 2):1473-1487. doi:10.1017/S0954579413000722

12. Rabinowitz JA, Osigwe I, Drabick DAG, Reynolds MD. Negative emotional reactivity moderates the relations between family cohesion and internalizing and externalizing 
medRxiv preprint doi: https://doi.org/10.1101/2022.02.08.22270624; this version posted February 9, 2022. The copyright holder for this preprint (which was not certified by peer review) is the author/funder, who has granted medRxiv a license to display the preprint in perpetuity. It is made available under a CC-BY-NC-ND 4.0 International license .

symptoms in adolescence. J Adolesc. 2016;53:116-126.

doi:10.1016/j.adolescence.2016.09.007

13. Copeland WE, Brotman MA, Costello EJ. Normative Irritability in Youth: Developmental Findings From the Great Smoky Mountain Study. J Am Acad Child Adolesc Psychiatry. 2015;54(8):635-642. doi:10.1016/j.jaac.2015.05.008

14. Amsel A. The role of frustrative nonreward in noncontinuous reward situations. Psychol Bull. 1958;55(2):102-119. doi:10.1037/h0043125

15. Insel T, Cuthbert B, Garvey M, et al. Research Domain Criteria (RDoC): Toward a New Classification Framework for Research on Mental Disorders. Am J Psychiatry. 2010;167(7):748-751. doi:10.1176/appi.ajp.2010.09091379

16. Leibenluft E. Pediatric irritability: A systems neuroscience approach. Trends Cogn Sci. 2017;21(4):277-289. doi:10.1016/j.tics.2017.02.002

17. Stringaris A, Goodman R, Ferdinando S, et al. The Affective Reactivity Index: a concise irritability scale for clinical and research settings. J Child Psychol Psychiatry. 2012;53(11):1109-1117. doi:10.1111/j.1469-7610.2012.02561.x

18. Holtzman S, O'Connor BP, Barata PC, Stewart DE. The Brief Irritability Test (BITe): A Measure of Irritability for Use Among Men and Women. Assessment. 2015;22(1):101-115. doi:10.1177/1073191114533814

19. Cardinale EM, Freitag GF, Brotman MA, Pine DS, Leibenluft E, Kircanski K. Phasic Versus Tonic Irritability: Differential Associations With Attention-Deficit/Hyperactivity Disorder Symptoms. J Am Acad Child Adolesc Psychiatry. Published online January 10, 2021. doi:10.1016/j.jaac.2020.11.022

20. Hawes MT, Carlson GA, Finsaas MC, Olino TM, Seely JR, Klein DN. Dimensions of irritability in adolescents: longitudinal associations with psychopathology in adulthood. Psychol Med. Published online October 2019:1-9. doi:10.1017/S0033291719002903

21. Silver J, Carlson GA, Olino TM, et al. Differential outcomes of tonic and phasic irritability in adolescent girls. J Child Psychol Psychiatry. 2021;62(10):1220-1227. doi:10.1111/jepp.13402

22. Riglin L, Eyre O, Thapar AK, et al. Identifying Novel Types of Irritability Using a Developmental Genetic Approach. Am J Psychiatry. 2019;176(8):635-642. doi:10.1176/appi.ajp.2019.18101134

23. Ebesutani C, Bernstein A, Nakamura BJ, Chorpita BF, Weisz JR. A Psychometric Analysis of the Revised Child Anxiety and Depression Scale-Parent Version in a Clinical Sample. $J$ Abnorm Child Psychol. 2010;38(2):249-260. doi:10.1007/s10802-009-9363-8 
medRxiv preprint doi: https://doi.org/10.1101/2022.02.08.22270624; this version posted February 9, 2022. The copyright holder for this preprint (which was not certified by peer review) is the author/funder, who has granted medRxiv a license to display the preprint in perpetuity. It is made available under a CC-BY-NC-ND 4.0 International license .

24. Burton CL, Wright L, Shan J, et al. SWAN scale for ADHD trait-based genetic research: a validity and polygenic risk study. J Child Psychol Psychiatry. 2019;60(9):988-997. doi:10.1111/jcpp.13032

25. Yu C yun. Evaluating Cutoff Criteria of Model Fit Indices for Latent Variable Models with Binary and Continuous Outcomes.; 2002.

26. Wolff HG, Preising K. Exploring item and higher order factor structure with the SchmidLeiman solution: Syntax codes for SPSS and SAS. Behav Res Methods. 2005;37(1):48-58. doi:10.3758/BF03206397

27. Dunn TJ, Baguley T, Brunsden V. From alpha to omega: a practical solution to the pervasive problem of internal consistency estimation. Br J Psychol Lond Engl 1953. 2014;105(3):399-412. doi:10.1111/bjop.12046

28. Watkins MW. The reliability of multidimensional neuropsychological measures: from alpha to omega. Clin Neuropsychol. 2017;31(6-7):1113-1126.

doi:10.1080/13854046.2017.1317364

29. Flora DB. Your Coefficient Alpha Is Probably Wrong, but Which Coefficient Omega Is Right? A Tutorial on Using R to Obtain Better Reliability Estimates. Adv Methods Pract Psychol Sci. 2020;3(4):484-501. doi:10.1177/2515245920951747

30. Rodriguez A, Reise SP, Haviland MG. Applying Bifactor Statistical Indices in the Evaluation of Psychological Measures. J Pers Assess. 2016;98(3):223-237. doi:10.1080/00223891.2015.1089249

31. Rosseel Y. lavaan: An R Package for Structural Equation Modeling. J Stat Softw. 2012;48(1):1-36. doi:10.18637/jss.v048.i02

32. Steiner M, Grieder S. EFAtools: An R package with fast and flexible implementations of exploratory factor analysis tools. J Open Source Softw. 2020;5(53):2521. doi:10.21105/joss.02521

33. Hittner JB, May K, Silver NC. A Monte Carlo evaluation of tests for comparing dependent correlations. J Gen Psychol. 2003;130(2):149-168. doi:10.1080/00221300309601282

34. Nimon K, Lewis M, Kane R, Haynes RM. An R package to compute commonality coefficients in the multiple regression case: An introduction to the package and a practical example. Behav Res Methods. 2008;40(2):457-466. doi:10.3758/BRM.40.2.457

35. Vittinghoff E, Glidden DV, Shiboski SC, McCulloch CE. Predictor Selection. In: Vittinghoff E, Glidden DV, Shiboski SC, McCulloch CE, eds. Regression Methods in Biostatistics: Linear, Logistic, Survival, and Repeated Measures Models. Statistics for Biology and Health. Springer US; 2012:395-429. doi:10.1007/978-1-4614-1353-0_10 
medRxiv preprint doi: https://doi.org/10.1101/2022.02.08.22270624; this version posted February 9, 2022. The copyright holder for this preprint

(which was not certified by peer review) is the author/funder, who has granted medRxiv a license to display the preprint in perpetuity.

36. Strout WF. A new item response theory modeling approach with applications to unidimensionality assessment and ability estimation. Psychometrika. 1990;55(2):293-325. doi:10.1007/BF02295289

37. Wiggins JL, Mitchell C, Stringaris A, Leibenluft E. Developmental trajectories of irritability and bidirectional associations with maternal depression. $J$ Am Acad Child Adolesc Psychiatry. 2014;53(11):1191-1205, 1205.e1-4. doi:10.1016/j.jaac.2014.08.005 
Running Head: Heterogeneity of Irritability

Table 1: Sample Characteristics

\begin{tabular}{|c|c|c|}
\hline & $\begin{array}{l}\text { Parent-Report } \\
\text { Overall } \\
(\mathrm{N}=3875)\end{array}$ & $\begin{array}{c}\text { Self-Report } \\
\text { Overall } \\
(\mathrm{N}=\mathbf{5 1 6})\end{array}$ \\
\hline Female $(\mathrm{n}, \%)$ & $1882(48.6 \%)$ & $305(59.1 \%)$ \\
\hline Value & Mean (SD) & Mean (SD) \\
\hline Age & $8.91(2.29)$ & $15.2(1.93)$ \\
\hline \multicolumn{3}{|l|}{ Trait Measures } \\
\hline Anxiety $(\mathrm{N}$ parent $=1554 ; \mathrm{N}$ self $=109)$ & $5.49(4.46)$ & $12.2(8.40)$ \\
\hline Depression $(\mathrm{N}$ parent $=1555, \mathrm{~N}$ self $=109)$ & $3.07(3.10)$ & $9.38(6.60)$ \\
\hline ADHD $(\mathrm{N}$ parent $=3867, \mathrm{~N}$ self $=516)$ & $-0.48(0.99)$ & $-0.60(0.92)$ \\
\hline
\end{tabular}




\section{TIDES-13 Dimensions}

IRRIT

Ext. Reactivity

P. Anger

R. Aggression

Int. Reactivity
$-0.34(1.16)$

$-0.22(1.13)$

$-0.22(1.33)$

$-0.96(1.42)$

$0.02(1.22)$
$-0.31(1.14)$

$-0.23(1.14)$

$-0.43(1.38)$

$-0.95(1.38)$

$0.36(1.32)$

\footnotetext{
Notes: $\mathrm{ADHD}=$ Attention-deficit/hyperactivity disorder, anxiety $=$ Anxiety, depression $=$ Depression, ODD $=$ Oppositional Defiant Disorder, Ext. Reactivity $=$ externalized Negative Emotional Reactivity sub-dimensions; R. Aggression $=$ Reactive Aggression sub-dimensions; P. Anger $=$ Proneness to Anger sub-dimension; Int. Reactivity = internalized Negative Emotional Reactivity; $\mathrm{M}=$ mean; $\mathrm{SD}=$ Standard Deviation, parent $=$ parent-reported data, self $=$ self-reported data .
} 
22 Fable 2: Pearson correlations and 95 CI between TIDES sub-dimensions, ARI and other psychopathology.

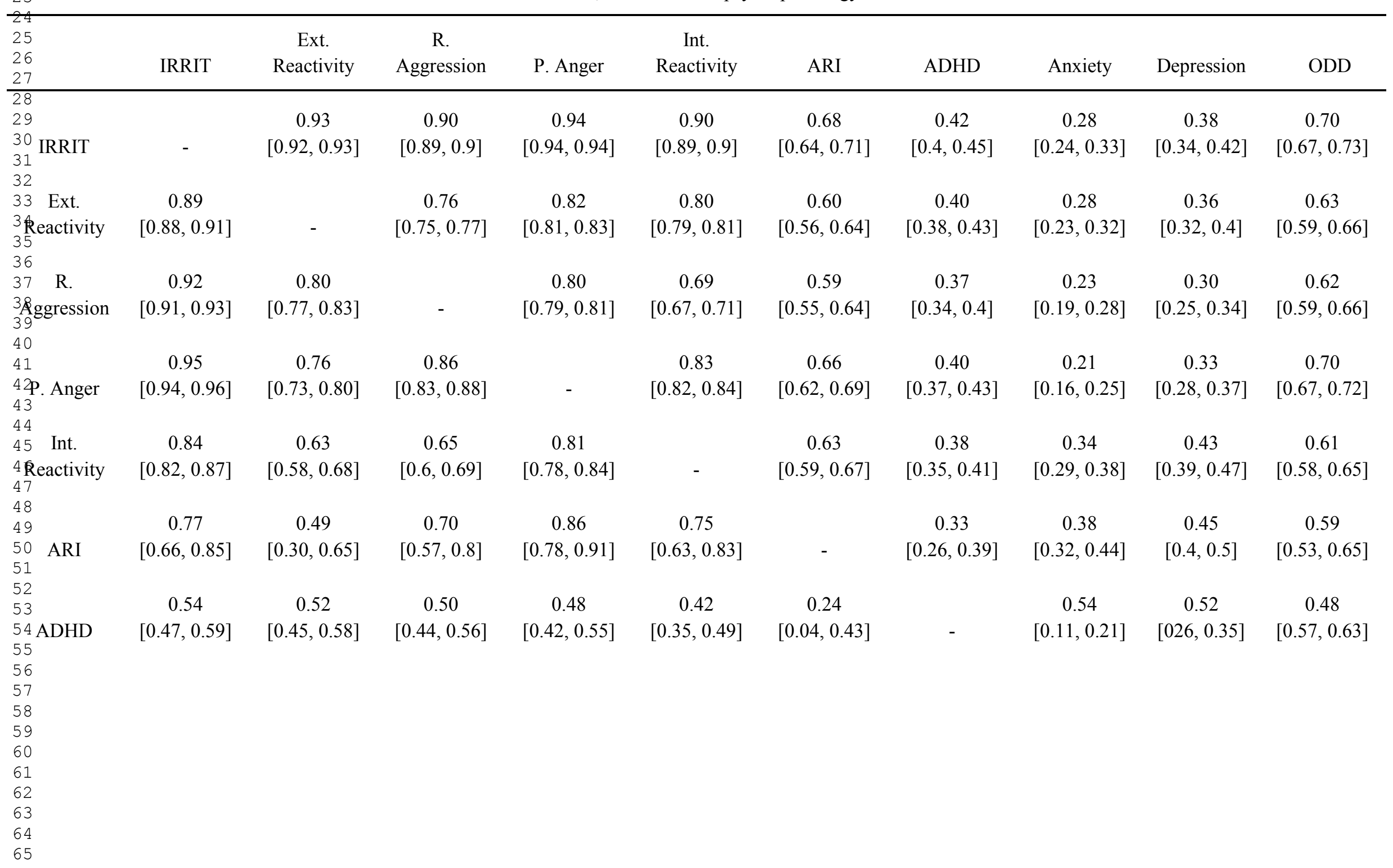


0.30

$0.03^{\text {n.s }}$

0.54

0.20

$0.32^{\mathrm{n} . \mathrm{s}}$

0.73

$[0.12,0.46$

$[0.13,0.47]$

$[-0.15,0.22]$

[0.05, 0.4]

$[0.4,0.66]$

$[-0.01,0.38]$

$[0.15,0.47]$

$[0.64,0.8]$

$[0.28,0.38]$

28

29

0.38

0.39

0.43

0.34

$0.19^{\text {n.s }}$

$0.23^{\text {n.s }}$

0.40

$0.2^{\mathrm{n} . \mathrm{s}}$

$-0.06^{\mathrm{n} . \mathrm{s}}$

$[0.19,0.63]$

$[0.08,0.55]$

$[-0.08,0.44]$

$[-0.12,0.53]$

[0.24, 0.54]

$[-0.03,0.44]$

$[-0.3,0.19]$ 
Table 3: Schmid-Leiman Transformed Standardized factor loadings, Fit indices, and Reliability estimates of TIDES-13

\begin{tabular}{|c|c|c|c|c|c|c|c|c|c|c|}
\hline \multirow[b]{2}{*}{ Tides Item } & \multicolumn{5}{|c|}{ Parent Report $(\mathrm{n}=1940)^{\dagger}$} & \multicolumn{5}{|c|}{ Self Report $(n=516)$} \\
\hline & IRRIT & $\begin{array}{l}\text { Ext. } \\
\text { Reacti } \\
\text { vity }\end{array}$ & $\begin{array}{l}\text { R. } \\
\text { Aggr } \\
\text { essio } \\
\mathrm{n}\end{array}$ & P. Anger & $\begin{array}{l}\text { Int. } \\
\text { Reactivity }\end{array}$ & IRRIT & $\begin{array}{l}\text { Ext. } \\
\text { Reactivity }\end{array}$ & $\begin{array}{l}\mathrm{R} . \\
\text { Aggressio } \\
\mathrm{n}\end{array}$ & P. Anger & $\begin{array}{l}\text { Int. } \\
\text { Reactivity }\end{array}$ \\
\hline $\begin{array}{l}\text { 10. Complains or } \\
\text { whines }\end{array}$ & 0.72 & 0.22 & & & & 0.63 & 0.26 & & & \\
\hline $\begin{array}{l}\text { 7. Angry when } \\
\text { not getting what } \\
\text { they want }\end{array}$ & 0.83 & 0.26 & & & & 0.72 & 0.30 & & & \\
\hline 9. Explosive & 0.73 & & 0.44 & & & 0.67 & & 0.32 & & \\
\hline
\end{tabular}


12. Physically $0.80 \quad 0.48$ aggressive

13. Verbally

offensive

2. Temper

0.89

Tantrums

5. Loose temper $\quad 0.91$

3. Easily

0.80

frustrated

4. Annoyed by

0.82

minor things

6. Annoyed by

0.89

others

\section{Fit Indices}

CFI
0.78

0.37

0.44

0.61

0.29

0.19

0.76

0.24

0.20

0.81

0.25

0.20

0.87

0.27

0.33

0.73

0.46

0.34

0.71

0.45

0.32

0.68

0.42 


\section{Reliability \\ Indices}

$\omega_{\text {Total }}$

Notes: IRRIT = Global Irritability dimension; Ext. Reactivity = externalized Negative Emotional Reactivity sub-dimension; R. Aggression $=$ Reactive Aggression sub-dimension; P. Anger $=$ Proneness to Anger sub-dimension; Int. Reactivity $=$ internalized Negative Emotional Reactivity sub-dimension; CFI = comparative fit index; TLI = Tucker Lewis Index; RMSEA = root mean square error of approximation; ${ }^{\dagger}$ the parameters in this table were calculated by transforming the loadings from the best fitting factor model in confirmatory factor analysis so only the confirmatory parent sample was used. 
Table 4: Multiple regression results of associations between TIDES sub-dimensions with Anxiety, Depression, ODD, and ADHD traits.

\begin{tabular}{|c|c|c|c|c|c|c|c|c|c|c|}
\hline \multirow[b]{2}{*}{ DV } & \multirow[b]{2}{*}{ IV } & \multicolumn{4}{|c|}{ Parent Report } & \multicolumn{5}{|c|}{ Self Report } \\
\hline & & $\mathrm{B}[95 \mathrm{CI}]$ & $\begin{array}{l}\text { Model } \\
\mathrm{R}^{2}(\%)\end{array}$ & $\begin{array}{l}\text { Unique } \\
\mathrm{R}^{2}(\%)\end{array}$ & $\begin{array}{l}\text { Shared } \\
\mathrm{R}^{2}(\%)\end{array}$ & B & $95 \mathrm{CI}$ & $\begin{array}{c}\text { Model } \\
\mathrm{R}^{2}\end{array}$ & $\begin{array}{c}\% \text { Unique } \\
\mathrm{R}^{2}\end{array}$ & $\begin{array}{c}\% \text { Shared } \\
\mathrm{R}^{2}\end{array}$ \\
\hline \multicolumn{11}{|l|}{ Internalizing } \\
\hline \multirow[t]{4}{*}{ Anxiety traits } & $\begin{array}{c}\text { Ext. } \\
\text { Reactivity }\end{array}$ & $0.45^{*}[0.05,0.79]$ & & 2.2 & & 0.44 & {$[-1.74,2.61]$} & & 1.2 & \\
\hline & $\begin{array}{c}\text { R. } \\
\text { Aggression }\end{array}$ & $0.17[-0.09,0.34]$ & & 0.7 & & 0.47 & {$[-1.42,236]$} & & 0.1 & \\
\hline & P. Anger & $-0.69^{* * *}[-1.07,-0.34]$ & & 6.4 & & -1.55 & {$[-3.42,0.32]$} & & 9.3 & \\
\hline & $\begin{array}{c}\text { Int. } \\
\text { Reactivity }\end{array}$ & $\mathbf{1 . 4 5}^{* * *}[1.2,1.8]$ & & 32 & & $\begin{array}{c}3.47^{* *} \\
*\end{array}$ & {$[1.42,5.36]$} & & 62.1 & \\
\hline
\end{tabular}


Ext.

$$
0.33[-0.3,0.46]
$$

Reactivity

$$
\text { R. } \quad 0.20^{*}[0.05,0.37]
$$

Int.

$\mathbf{0 . 9 2} 2^{* * *}[0.84,1.3]$

\section{Reactivity}

20.5

54.4

Ext.

Reactivity

R.

Aggression

P. Anger

Int.

Reactivity
$0.27 \quad[-1.48,2.02]$ 


$$
\text { Ext. } \quad \mathbf{0 . 1 6}^{* * *} \quad[0.08,0.18]
$$

\section{Reactivity}

R

$$
0.08^{* * *} \quad[0.06,0.13]
$$

Aggression

$$
\text { P. Anger }
$$

0.0

$[0.01,0.11]$

0.61

Int.

$$
0.1^{* * *} \quad[0.06,0.15]
$$

Reactivity
Notes: $\mathrm{DV}=$ Dependent Variable, IV = Independent Variable, $\mathrm{B}=$ Beta coefficient, $\mathrm{CI}=$ Confidence Interval, Ext. Reactivity $=$ Externalized Negative Emotional Reactivity sub-dimension; R. Aggression $=$ Reactive Aggression sub-dimension; P. Anger $=$ Proneness to Anger sub-dimension; Int. Reactivity = Internalized Negative Emotional Reactivity sub-dimension; Model $\mathrm{R}^{2}=$ percentage of the dependent variable's variance explained by the overall model. \% Unique $\mathrm{R}^{\wedge} 2=$ percentage of the variance explained by the model that is unique to each corresponding sub-dimension; $\%$ Shared $\mathrm{R}^{\wedge} 2=$ ercentage of the variance explained by the model that is common to all sub-dimensions, and therefore represents the global irritability dimension. $* \mathrm{p}<0.05 ; * * \mathrm{p}<0.01 ; * * * \mathrm{p}<0.001$. The strongest significant predictor of a given trait is bolded. 


\section{Figure Captions}

Figure 1: Higher Order Model of Irritability and Factor loadings. Both parent-reported (A) and self-reported (B) The Irritability and Dysregulation of Emotion Scale (TIDES-13) scores showed a higher order model of irritability with a global irritability dimension (IRRIT) and externalized negative emotional reactivity (Ext. Reactivity), reactive aggression (R.

Aggression), proneness to anger (P. Anger), internalized negative emotional reactivity (Int. Reactivity). The numbers on the straight lines represent the standardized loading. The numbers places around the circular arrows represents the corresponding variable's variance. 


\section{A: Parent Report}

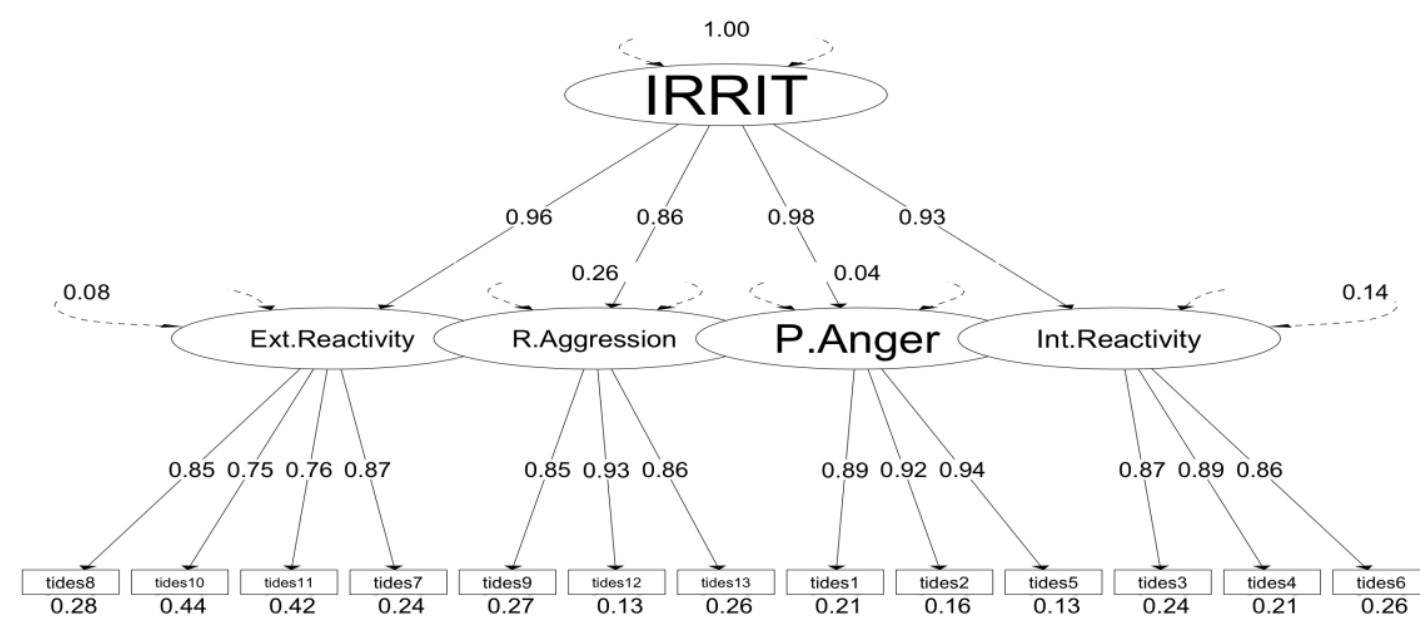

\section{B: Self Report}

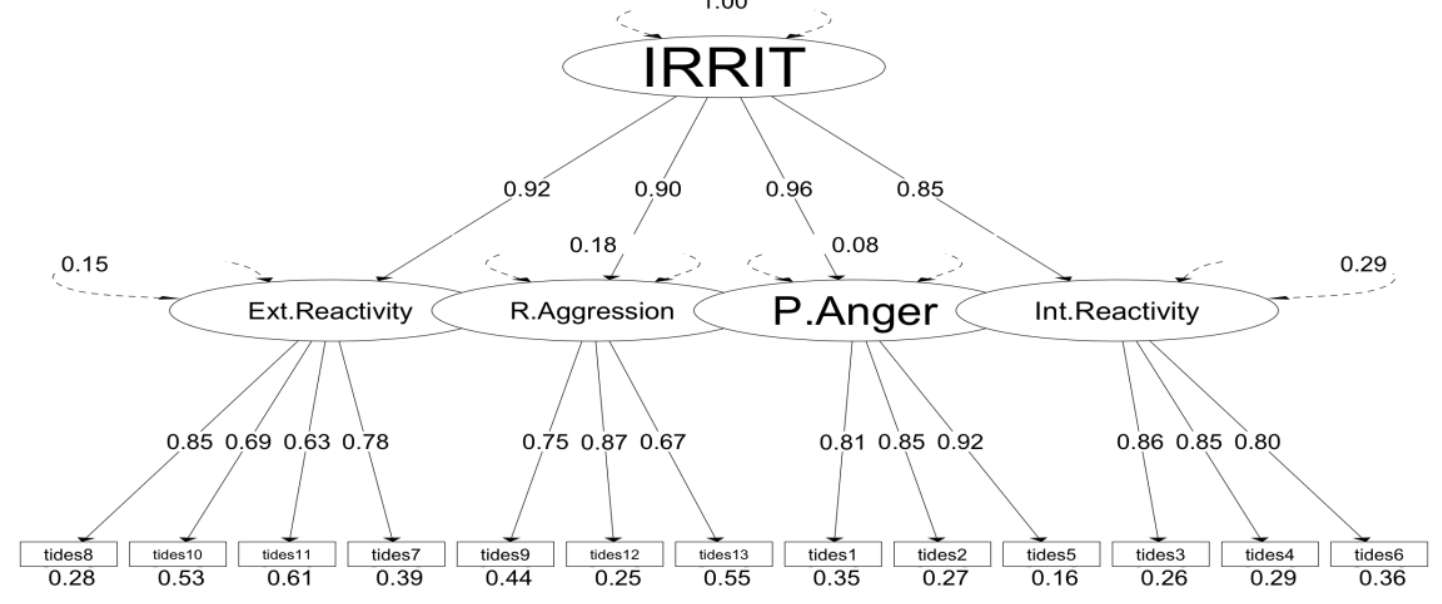




\section{Supplementary material}

Table S1: CFA Model Fit indices

\begin{tabular}{|c|c|c|c|c|c|c|c|c|}
\hline \multirow[b]{2}{*}{ Model } & \multicolumn{4}{|c|}{ Parent Report } & \multicolumn{4}{|c|}{ Self Report } \\
\hline & CFI & TLI & RMSEA & SRMR & CFI & TLI & RMSEA & SRMR \\
\hline Unidimensional & 0.902 & 0.899 & 0.139 & 0.047 & 0.883 & 0.859 & 0.125 & 0.058 \\
\hline 2 Dimension & 0.947 & 0.935 & 0.1 & 0.033 & 0.9 & 0.878 & 0.116 & 0.054 \\
\hline 3 Dimension & 0.964 & 0.954 & 0.087 & 0.031 & 0.939 & 0.921 & 0.096 & 0.054 \\
\hline 4 Dimension & $.979 \dagger$ & $.972 \dagger$ & $.068 \dagger$ & $.023 \dagger$ & $.966 \dagger$ & $.955 \dagger$ & $.070 \dagger$ & $.040 \dagger$ \\
\hline H 2 Dimension & 0.95 & 0.939 & 0.101 & 0.033 & 0.9 & 0.877 & 0.117 & 0.054 \\
\hline H 3 Dimension & 0.962 & 0.952 & 0.088 & 0.030 & 0.929 & 0.911 & 0.099 & 0.051 \\
\hline H 4 Dimension & 0.972 & 0.964 & 0.076 & 0.028 & 0.957 & 0.944 & 0.078 & 0.044 \\
\hline
\end{tabular}

Notes: $\mathrm{CFA}=$ confirmatory factor analysis; $\mathrm{CFI}=$ comparative fit index; TLI = tucker lewis index; RMSEA = root mean square error of approximation; SRMR = standardised root mean residual; $\mathrm{H}=$ higher order model with additional higher order global dimensions, $\uparrow=$ best fitting model. This table summarizes the confirmatory factor analysis fit indices of multiple factor models extracted from exploratory factor analysis conducted in a separate exploratory sample. 
Table S2: Associations of TIDES sub-dimensions with Age and Gender

\section{Dependent variable:}

\begin{tabular}{ccccc}
\hline IRRIT & P. Anger & Int. Reactivity & Ext. Reactivity & R. Aggression \\
Beta & Beta & Beta & Beta & Beta
\end{tabular}

(Std. Error) (Std. Error) $\quad$ (Std. Error) (Std. Error) Error)

Sample Overall Female Male Overall Female Male Overall Female Male Overall Female Male Overall Female Male

\begin{tabular}{|c|c|c|c|c|c|c|c|c|c|c|c|c|c|c|c|}
\hline Age & $\begin{array}{c}0.015 \\
(0.010)\end{array}$ & $\begin{array}{c}0.003 \\
(0.011)\end{array}$ & $\begin{array}{c}- \\
\mathbf{0 . 0 2 8} \\
* \\
(0.01 \\
1)\end{array}$ & $\begin{array}{c}0.007 \\
(0.011)\end{array}$ & $\begin{array}{l}-0.011 \\
(0.012)\end{array}$ & $\begin{array}{c}- \\
\mathbf{0 . 0 4 5} \\
* * * \\
(0.01 \\
2)\end{array}$ & $\begin{array}{c}0.045^{* * *} \\
(0.010)\end{array}$ & $\begin{array}{l}\mathbf{0 . 0 3 3}^{\text {***}} \\
(0.011)\end{array}$ & $\begin{array}{c}0.010 \\
(0.012)\end{array}$ & $\begin{array}{c}0.009 \\
(0.010)\end{array}$ & $\begin{array}{l}-0.005 \\
(0.011)\end{array}$ & $\begin{array}{c}\text { - }^{* * *} \\
\mathbf{0 . 0 4 1}^{* *} \\
(0.011)\end{array}$ & $\begin{array}{c}0.002 \\
(0.012)\end{array}$ & $\begin{array}{l}-0.003 \\
(0.013)\end{array}$ & $\begin{array}{c}- \\
\mathbf{0 . 0 5 0}^{* * *} \\
(0.013)\end{array}$ \\
\hline Gender & & & & & & & & & & & & & & & \\
\hline Female & ref. & & & ref. & & & ref. & & & ref. & & & ref. & & \\
\hline Respondent & & & & & & & & & & & & & & & \\
\hline Parent & ref. & & & ref. & & & ref. & & & ref. & & & ref. & & \\
\hline Self & $\begin{array}{c}0.080 \\
(0.072)\end{array}$ & $\begin{array}{c}\mathbf{0 . 2 3 2}^{*} \\
(0.095)\end{array}$ & $\begin{array}{c}- \\
0.098 \\
(0.10 \\
8)\end{array}$ & $\begin{array}{c}-0.082 \\
(0.080)\end{array}$ & $\begin{array}{c}0.056 \\
(0.106)\end{array}$ & $\begin{array}{c}- \\
\mathbf{0 . 2 4 5} \\
* \\
(0.12 \\
0)\end{array}$ & $\begin{array}{l}0.199^{* *} \\
(0.076)\end{array}$ & $\begin{array}{c}\mathbf{0 . 3 6 0} \text { *** } \\
(0.100)\end{array}$ & $\begin{array}{c}0.010 \\
(0.116)\end{array}$ & $\begin{array}{l}0.313^{* * *} \\
(0.072)\end{array}$ & $\begin{array}{l}\mathbf{0 . 4 9 0}{ }^{* * *} \\
(0.096)\end{array}$ & $\begin{array}{c}0.105 \\
(0.108)\end{array}$ & $\begin{array}{c}0.172^{*} \\
(0.087)\end{array}$ & $\begin{array}{c}\mathbf{0 . 2 3 4}^{*} \\
(0.116)\end{array}$ & $\begin{array}{c}0.099 \\
(0.132)\end{array}$ \\
\hline Age:Gender & $\begin{array}{c}\mathbf{- 0 . 0 5 5}^{* * *} \\
(0.012)\end{array}$ & & & $\begin{array}{c}\mathbf{- 0 . 0 5 5}^{* * *} \\
(0.013)\end{array}$ & & & $\begin{array}{c}-\mathbf{0 . 0 4 8}^{* * *} \\
(0.012)\end{array}$ & & & $\begin{array}{c}\overline{-}^{\text {0.063** }} \\
(0.012)\end{array}$ & & & $-0.057^{* * *}$ & & \\
\hline
\end{tabular}


Notes: Ext. Reactivity $=$ Externalized Negative Emotional Reactivity sub-dimension; $R$. AGGR $=$ Reactive Aggression sub-dimension; $P$. Anger = Proneness to Anger sub-dimension; Int. Reactivity = Internalized Negative Emotional Reactivity sub-dimension, Std. Error $=$ standard error, ref = reference category for categorical variables. Beta coefficients estimated for categorical variables are in comparison to the reference category. ${ }^{*} \mathrm{p}<0.05 ;{ }^{* *} \mathrm{p}<0.01 ;{ }^{* * *} \mathrm{p}<0.001$. This table summarizes the results from multiple regression analyses examining the association between TIDES-13 sub-dimensions with age and gender. Gender-stratified analyses were undertaken when the Age: Gender interaction term was significant. 


\section{TIDES-13 Development}

We began by reviewing the existing definitions of irritability and identifying components within these definitions including proneness to anger (phasic irritability), negative emotional reactivity, grumpy or grouchy mood (tonic irritability), and reactive aggression. We then created a large pool of candidate items corresponding to these five components from existing irritability measures. Responses were measured from strengths ( -3$)$ to weakness (3) to capture the full distribution of irritability in a general population sample. The existing item pool was administered to a development sample consisting of parents of children attending a psychiatric clinic at [XXXXXXXXX] Hospital $(n=149)$. Parents responding to the items were asked a list of qualitative questions probing their interpretations of each item. These results informed item modification and deletion. Items were further deleted based on low itemscale correlation, low contributions to internal consistency, and considerations of face validity. After these final modifications, we arrived at the 13-item scale used in this present study. TIDES-13 has two parts: the first is 13 -item measure of irritability traits on a continuum, where parents/youth were asked to rate the participant/themselves compared to others of the same age over the past year on a 7-point Likert scale ranging from -3 (far less than others) to 3 (far more than others). The second part of the scale contains four additional items measuring the frequency of temper outbursts, frequency of physically aggressive outbursts and level of the irritabilityrelated impairment, all of which correspond to DSM-5 criterion for DMDD and IED to aid in establishing research diagnoses. 


\section{Exploratory Factor Analysis (EFA) Methods}

In EFA, the number of factors to retain was informed by parallel analyses and the scree test. EFA models were extracted using varimax rotations in anticipation of highly correlated factors. We assigned items to factors when the factor loading was greater than 0.4. All EFA analysis was conducted using the stats package that runs freely in R studio.

\section{Exploratory Factor Analysis Results:}

Parallel analysis suggested extracting four factors, however visual examination of the scree plot for "elbowing" was not clearly distinguishable between two, three and four-factor solutions so we extracted all one through four- factor solutions to determine the number of sub-dimensions that best described TIDES-13-dimensional structure. The first was a unidimensional model with all items loading onto one latent variable. The two-factor model had two factors: Reactive Aggression and the remaining items. The three-factor model had mood, phasic, and reactive aggression factors. The four-factor factor model had externalized negative emotional reactivity (Ext. Reactivity), reactive aggression (R. Aggr), proneness to anger (P. Anger), internalized negative emotional reactivity (Int. Reactivity) factors. 